\title{
The Relationship between the Organizational Alienation and the Organizational Citizenship Behaviors of Primary School Teachers
}

\author{
Abidin Dağlı ${ }^{1, *}$, Emel Averbek $^{2}$ \\ ${ }^{1}$ Department of Educational Administration, Ziya Gokalp Education Faculty, Dicle University, Turkey \\ ${ }^{2}$ Mehmet Akif Nuhoglu Vocational and Technical Anatolian High School, Turkey
}

Copyright $\bigcirc 2017$ by authors, all rights reserved. Authors agree that this article remains permanently open access under the terms of the Creative Commons Attribution License 4.0 International License

\begin{abstract}
The aim of this study is to determine the relationship between the organizational alienation and the organizational citizenship behaviors of primary school teachers. The research population consists of 700 teachers from 90 primary schools in the central district of Mardin/Turkey in the academic year of 2015-2016. The research sample consists of randomly selected 346 teachers from 40 primary schools. Some of the important findings; (1) The perceptions of the primary school teachers about organizational alienation were found to be in the dimension of "powerlessness" $(\mathrm{M}=1.94)$ "normlessness" $(\mathrm{M}=2.16)$, "isolation" ( $\mathrm{M}=1.87)$, "self-estrangement" $(\mathrm{M}=1.86$, Rarely) and "meaninglessness" $(\mathrm{M}=1.66$, Never $)$. As for the score regarding the whole scale, it was found to be $(\mathrm{M}=1.87$, Rarely). (2) The perceptions of the primary school teachers about organizational citizenship behaviors were found to be in the dimension of "civic virtue" $(\mathrm{M}=3.86)$, "altruism" $(\mathrm{M}=4.15)$, "conscientiousness" $(\mathrm{M}=4.20$, I agree $)$ and "gentility" ( $\mathrm{M}=4.21$; I totally agree). The score regarding the whole scale was found to be (M=4.11; I agree). (3) In the study, the relationship between organizational alienation and organizational citizenship behaviors was detected as $(r=$ $-.510, p<.01$ ) a mid-level, significant and negative oriented correlation. It was found out in this study that the more organizational alienation behaviors, the less organizational citizenship behaviors.
\end{abstract}

Keywords Alienation, Organizational Alienation, Organizational Citizenship Behavior

\section{Introduction}

Mankind has played the leading role in the continuously changing order of the world where we live. Human beings have, by nature, thought, discovered, produced and developed and it has been essential for humans to discover themselves first in order to achieve these activities. They will accomplish and maintain this unavoidable development by means of the innovations that they will discover and improve within themselves. However, inadequate or improper methods and strict rules prevent them from realizing their potentials by removing individuals from their selves and cause them to lose the control, the result of which is alienation. Alienation may undermine individuals' development [1].

The concept of alienation has entered in Turkish language from western languages and the root of the word is based on "aléné" in French and "alienado" in Spanish and "alienation" in English [2]. Generally, the concept of alienation can be defined as a decline in an individual's adaptation to her/his social, cultural and natural surrounding and especially in an individual's control over his/her close surrounding, which causes loneliness and despair [3]. As its source, the word "alienation" implies an intense separation first from the objects in a world, second from other people, third from ideas about the world held by other people [4]. Alienation is regarded as a case of estrangement or withdrawal, disillusionment or stress $[5,6,7]$. Alienation has been identified with a number of problems and negative consequences [8].

Alienation can be described as a sense of estrangement from other human beings, from society and its values, and from the self, particularly from those parts of the self that link it to others, and to society at large [7].Human alienation often occurs when a person has a negative attitude towards people and the world and experiences a feeling that leads to unhappiness. One can be alienated from one's family, society, religion or culture. Oliver (2004) refers to human alienation as 'a zone of nonbeing'; since a person's being is affirmed by being accepted and valued by other members of his/her own community or family, that person feels worthless when rejected [9]. The symptoms of alienation are estrangement, 
apathy, inability to be deeply committed to anything, lack of work engagement, retreating, disconnection in relationships and isolation [10].

Moch (1980) points out the fact that the concept of organizational alienation refers to an attitude or a condition in which an employee cares little about work, approaches work with little energy and works primarily for extrinsic rewards [11] or it means the impossibility of meeting employees' social requirements [12].

Seeman [13] evaluated alienation in terms of socio-psychological view and postulated five dimensions -powerlessness, meaninglessness, normlessness, isolation, and self-estrangement. These dimensions are described briefly below.

1. Powerlessness: According to Blauner (1964) and West (1998), Powerlessness is a situation created by a bad mood in which individuals are unable to conduct the organizational activities or decide on their own [14].

2. Meaninglessness: It is a case of disharmony caused by the fact that individuals cannot evaluate themselves truly and think that their behaviors are shaped by other people's wills [15].

3. Normlessness (Anomie): In the traditional usage, anomie denotes a situation in which the social norms regulating individual conduct have broken down or is no longer effective as rules for behavior (Seeman, 1959). It can be defined as an imbalance which occurs as a result of the lack of aims or the collapse of values and dimensions within the individuals or in the society [16].

4. Isolation: It is the result of the fact that members of organizations retreat themselves from their surroundings and they feel incapable of belonging to any group or community [16].

5. Self-estrangement: Mottaz (1981) points out the fact that employees don't perform their job eagerly and they don't find their jobs interesting. They cannot make any connection between the things that they want to do and the job that they perform. Thus, they cannot experience the feeling of happiness resulting from success [14].

Diener (1984) points out the fact that self-esteem of alienated workers is likely to be low. Korman (1966) and Sirgy (1986) suggest that low self-esteem workers tend to have lower levels of performance and alienated workers feel incompetent, which leads to dissatisfaction with the job and an escape from work [17]. The consequences of feeling apart from one's society are little known. Several possibilities have been suggested: (1) That alienation is related to creativity, (2) That alienation is related to mental- emotional disorder,(3) That estranged people may be more sensitized to the wounds of anonymous other, (4) That the alienated suffer a proclivity to suicide, (5) That they are prone to the chemical addictions, (6) That they are poor marriage risks, (7) That their estrangement leads to criminal behavior [18].

The phenomenon of alienation in education turns out to be a problem that affects teachers directly. The employees in educational organizations become alienated from the processes about learning and teaching. These processes cause individuals to experience meaningless so they feel lack of concern for teaching process and education gets more and more boring and unpleasant [14].

Educational alienation cannot be dismissed as a purely temporary, easily treatable defect. Rather, it is a part of education that defines its essential tension [19]. Alienation in education prevents teachers from being creative, from being a model for the society and students, from improving themselves with regards to their jobs, from their contribution to social development, from being effective in teaching and learning processes, from being productive in teaching and from working in solidarity with school administrations and colleagues [20].

Nowadays, for organizations to survive, it is not enough for employees just to fulfill their formal duties in working environments based on competition. Thus, the success of organizations depends on employees behaving voluntarily beyond formal role descriptions. These kinds of behaviors are conceptualized as organizational citizenship behaviors (OCBs) in literature which has become one of the mostly researched studies [21].Organizational citizenship behaviors that were first used by Barnard in 1930s were defined as informal role-behaviors. Organizational citizenship behaviors are described as employees' extra role behaviors that they perform in order to contribute to organizations. Organizational behaviors were used by Dennis Organ in 1983 [15].

Organ (1988) describes OCB as "individual behavior that is discretionary, not directly or explicitly recognized by the formal reward system, and that in the aggregate promotes the effective functioning of the organization" [22].Organ (1988) suggests that it has been presented in the organizational literature as discretionary behaviors that go beyond those formally prescribed by the organization and for which there are no direct rewards [23].Citizenship behaviors cannot be rewarded by an organization's reward system [24].Organ (1988) points out the fact that derived from Katz's (1964) notion of extra-role behaviors, organizational citizenship behaviors (OCBs) have been defined as behaviors displayed by teachers that are discretionary, not directly or explicitly recognized by the formal reward system and that, in the aggregate, promote the effective functioning of an organization (school). These behaviors are often internally motivated, arising from and sustained by an individual's intrinsic need for a sense of achievement, competence, belonging or affiliation [25].

Katz and Kahn (1966) have noted the many occasions in which organizational functioning depends on supra-role behavior that cannot be prescribed or required in advance for a given job. These behaviors include any of those gestures that lubricate the social machinery of the organization but that do not directly in here in the usual notion of task performance. Examples that come to mind include; helping 
co-worker with a job-related problem; accepting orders without a fuss; tolerating temporary impositions without complaint; helping to keep the work area clean and uncluttered; making timely and constructive statements about the work unit or its head to outsiders; promoting a work climate that is tolerable and minimizes the distractions created by interpersonal conflict and protecting and conserving organizational resources [26].

Researchers have offered several explanations for this assumption. First, citizenship is thought to increase organization performance by reducing the need to allocate scarce resources to maintenance functions within organizations, thereby freeing up these resources for more productive purposes. Second, citizenship can act to improve coordination within work groups, thus reducing friction within organizations and improving effectiveness. Finally, by making them attractive places to work, organizations where citizenship is prevalent may be better able to attract and retain the best employees, thereby improving their performance [22].

Organ (1988) has identified five categories of OCBs or discretionary behaviors: Altruism, courtesy, sportsmanship, conscientiousness, and civic virtue [27].Many researchers used Organ's five dimensions [27, 28, 29, 30,31], so in this study, the dimensions described by Organ (1998) were used in.

1. Altruism: According to Organ (1998), altruism, refers to helping behaviors aimed at coworkers, customers, clients, vendors, or suppliers [32].Organ (1998) suggests that unlike courtesy which is meant to prevent a problem from happening, altruism is meant to provide help to someone who is already in trouble [33].Organ suggests that this dimension includes voluntary actions that help another person with a work problem, instructing a new hire on how to use equipment, helping a coworker catch up with a backlog of work, fetching materials that a colleague needs and cannot procure on his own [34].

2. Courtesy: Organ's $(1988,1990)$ notion of courtesy involves helping others by taking steps to prevent the creation of problems for coworkers and providing advance notice to someone who needs to know to schedule work providing advance notice to someone who needs to know to schedule work [34].

3. Organ (1998) argues that courtesy targets behaviors intended to mitigate problems or prevent problems from occurring. Courtesy behavior is also associated with maintaining the social order and reciprocating favors, both of which suggest the value of security. Courtesy behavior also indicates a sense of caring and responsibility, which is captured by the category of benevolence [33].

4. Conscientiousness: According to Organ's definition of this dimension, employees fulfill duties voluntarily that surpass minimal role requirements and perform more than the least expected behaviors such as participation in organization, usage of working times and obeying the rules [32].

5. Sportsmanship (Gentility): Organ (1990) has defined sportsmanship as "a willingness to tolerate the inevitable inconveniences and impositions of work without complaining." However, his definition seems somewhat narrower than the label of this construct would imply. For example, in our opinion "good sports" are people who not only do not complain when they are inconvenienced by others, but also maintain a positive attitude even when things do not go their way, are not offended when others do not follow their suggestions, are willing to sacrifice their personal interest for the good of the work group, and do not take the rejection of their ideas personally [34].

6. Civic virtue: It represents a macro-level interest in, or commitment to, the organization as a whole. This is shown by a willingness to participate actively in its governance (e.g., attend meetings, engage in policy debates, express one's opinion about what strategy the organization ought to follow, etc.) [34].

Podsakoff and MacKenzie[35]suggest that organizational citizenship behaviors increase the development of friendship with colleagues and administrative efficiency. Furthermore, organization citizenship behaviors attract employees by providing resources to be used for more useful purposes, by reducing the need to use scarce resources just for maintenance work and by organizing the activities among work groups or groups. Moreover, these behaviors strengthen organizations' capacity and stability and enable organizations to adapt to environmental changes. As a result, organizational citizenship behaviors contribute to the success of the organizations [32].

Organ (1998) suggested that organizational citizenship behavior effectively attributes financial and human resources as well as assists organizational efficiency in operations. In other words, Organ (1990) claims that employees surpass organizational requirements, not only completing their obligations and tasks but also initiating voluntary actions beyond their work roles, making sacrifices, helping others and offering advice [36].

Successful organizations have employees who go beyond their formal job responsibilities and freely give their time and energy to succeed at the task at hand. In terms of schools which are educational organizations, organizational citizenship behaviors of teachers are vital for the success of the schools. "Because OCBs smoothes the way for schools to make the adaptations and innovations necessary for long-term survival and growth" (DiPaola \& Tschannen-Moran, 2001; cited in [37]. Teaching is a complex activity that requires professional judgments; it cannot adequately be prescribed in teachers' job descriptions or contracts. Thus, organizational citizenship behavior is an especially important aspect of the performance of faculty in schools [38].Somech and Drach-Zahavy (2000) suggest that performance defined as prescribed by task roles is necessary 
but not sufficient for predicting school effectiveness [39].As Giroux (1995) has reiterated that citizenship and democracy need to be problematical and reconstructed for each generation. Public schools must assist in the unending work of preparing citizens for self-governance in an evolving social environment. Through the public schools, learners can be taught the values and skills necessary to administer, protect and perpetuate a free democratic society [40].

Organizational citizenship behaviors facilitate organizations' reform, adaptation to surroundings and transfer of the funds and saving resources. OCB increases quality of service, organizational, personal and group efficiency while it reduces expenses. There is an increase in job satisfaction, responsibility, solidarity and participating in decision-making voluntarily. Organizational citizenship behaviors supporting organizational learning boost students' success. Similarly, organizational citizenship behaviors have more advantages, for example, employees have positive feelings towards organizations and work, and so organizations attract workforce and have the ability to keep that force. Moreover, a decrease in the intention of leaving job, work transferring and work absenteeism is observed in organizations with high organizational citizenship behaviors. Organizational citizenship behaviors are regarded as social capital. The more satisfied consumers are the less they complain [32].

DiPaola and Tschannen-Moran (2001) suggest that OCB has become paramount because it smoothes the way for schools to make the adaptations and innovations necessary for long-term survival and growth [37].According to Somech and Drach-Zahavy (2000), schools will have to be more dependent on teachers who are willing to exert considerable effort beyond formal job requirements, namely, to engage in OCB [39].

As mentioned above, alienation prevents employees' creativity, improving themselves in professional aspects, their contribution to social development and effective working process. Teachers whose job is to teach a branch of science, art, technique or knowledge are affected negatively by alienation. Thus, it is essential to find out the level of alienation of teachers and precautions in that subject in order to enable teachers to work efficiently and productively. Employees are very crucial for the efficiency and performance of organizations and behaviors of employees in the organizations are important factors for the success of the work. Employees' voluntary usage of their experiences and abilities (beyond the standards) for the benefit of organizations are organizational citizenship behaviors. Organizational citizenship behaviors increase administrative efficiency and employees' productivity. Alienation is one of the factors that decrease work performance. Therefore, it is essential to determine primary school teachers' alienation in dimensions to do away with alienation and to detect the effects of alienation on organizational citizenship behaviors. This study is hoped to shed light on studies that will be carried out by administrators, teachers and researches.

\subsection{The Aim of the Study}

The aim of the study is to determine the relationship between the organizational alienation and the organizational citizenship behaviors of primary school teachers. It was tried to answer the questions below;

1. What is the range of the perceptions of primary school teachers regarding organizational alienation?

2. What is the range of the perceptions of primary school teachers regarding organizational citizenship behaviors?

3. Is there a meaningful relationship between organizational alienation and citizenship behaviors of primary school teachers?

\section{Method}

\subsection{The Model of the Study}

This study is in survey and relational survey model. In survey model, the person or the object of the study is tried to be determined in its own conditions as it is. In relational survey model, co-change existence and level of change between two or more variables together are investigated [41].

\subsection{Population and Sample}

The population of the study consists of primary school teachers in the central district of Mardin in the academic year of 2015-2016. There are 90 primary schools in the district of Mardin in Turkey and 700 primary teachers. The research sample consists of randomly selected 346 teachers from 40 primary schools.

\subsection{Data Collection Tools}

Organizational Alienation Scale and Organizational Citizenship Behavior Scale were used in this study. The information related to data collecting is described below:

1. Organizational Alienation Scale: Organizational Alienation Scale was developed and validity and reliability of the scale were carried out by Eryllmaz [42]. Based on the dimensions formed by Seeman [13], Organizational Alienation Scale is classified into five dimensions; powerlessness, meaninglessness, normlessness, isolation and self-estrangement. It was asked to an expertise view for content validity. The scale consists of five factors reflecting five dimensions. In factor analysis, eigenvalues and variance ratio are taken into consideration. Factor analysis shows items accumulating in independent five factors and items' factor values change between 0,41 and 0,75 . Correlation value is found to be 0,84 as a result of test-retest method used to detect whether the scale' invariant measures are met or not. In order to evaluate internal consistency reliability, Cronbach alpha coefficient changes between 0,67 and 0,89 which shows the scale is reliable. After all studies, there are five 
items for personal information in the scale and 38 items for organizational alienation level. The dimensions in the scale and items can be described as; 15 items for powerlessness (1, $2,3,4,5,6,7,8,9,10,11,12,13,14,15), 10$ items for meaninglessness $(16,17,18,19,20,21,22,23,24,24), 4$ items for normlessness $(26,27,28,29), 6$ items for isolation $(30,31,32,33,34,35)$ and 3 items for self-estrangement $(36,37,38)$. In this study, Cronbach alpha coefficient of the dimensions is evaluated and found as; 0,$94 ; 0,89 ; 0,64 ; 0,80$; 0,64 . It is 0,94 for the whole scale. When there are not many items in the scale, reliability co-efficient with 0.60 and over is also regarded reliable enough [43].Özdamar (1999) pointed out that evaluations are highly reliable when alpha reliability coefficient is between 0.60 and 0.90 [44].Thus, Cronbach Alpha reliability coefficient acquired through the evaluations is within the acceptable limits. The answers in the scale mean as follow; Always (5), Usually (4), Sometimes (3), Rarely (2) and Never (1).

2. Organizational Citizenship Scale: Organizational Citizenship Behaviors Scale based on the study by Organ (1988) was developed by Podsakoff and MacKenzie (1989) and later revised by Podsakoff, MacKenzie, Moorman \& Fetter (1990) and Moorman (1991), later it was translated into Turkish and validity and reliability were carried out by Polat [32].The scale based on the five dimensions of organizational citizenship behaviors. Before using the scale, Polat [32] tried to provide validity and reliability according to pilot scheme results and expert opinions. The scale is originally in English and it was translated by three people and the results were compared. After the questions in the scale were asked to a group of teachers and the comprehensible translation was done, the scale was adapted to educational organizations. Experts were asked for help to evaluate the content validity of the scale and the scale was re-organized with the help of three experts. After the application of the scale, factor analysis was done to test its construct-validity according to the findings and comments. As a result of the factor analysis, the original scale and the scale developed by Polat [32] was coherent. The factor values in the scale change between 0,49 and 0,84 . Cronbach alpha coefficient for the whole scale was 0,89 . Cronbach alpha coefficient in the dimension of altruism was 0,81 ; sportsmanship (gentility) was 0,81 ; conscientiousness was 0,88 and civic virtue was 0,86 . The original scale has five dimensions and this scale consists of four dimensions. The items in the dimensions of altruism and courtesy were included in one dimension. It was highlighted that the dimensions of altruism and courtesy were very similar to each other and both included helping others. According to Organ (1998) explanation of the difference between these dimensions, courtesy is performed before something bad happens and altruism occurs after something bad happens [32].Thus, the collection of two dimensions in one was an acceptable result. Other items in the scale and the original scale were coherent. As a result, the scale consists of 20 items and four dimensions; altruism, sportsmanship (gentility), conscientiousness and civic virtue. The dimensions and items in these dimensions; 8 items in Altruism $(1,2,3,4,5,6,7,8), 4$ items in sportsmanship $(9,10$, $11,12),$,4 items in Conscientiousness $(13,14,15,16)$ and 4 items in civic virtue $(17,18,19,20)$. Cronbach Alpha coefficients for the dimensions of this study are respectively 0,$85 ; 0,75 ; 0,81 ; 0,81$. The whole scale was detected to be 0,88 . The answers in the scale; I totally agree (5), I agree (4), I am undecided (3), I disagree (2) and I absolutely disagree (1).

\subsection{Data Analysis}

SPSS 20.0 packet programme was used for the analysis of the data. Frequencies were calculated according to some qualities of the working group. For the analysis of the data that reached at the end of the research; mean scores and standard deviations of the dimensions and the whole scale were calculated. Since the distribution of the scores is not normal, the nonparametric tests were used. Therefore, the relationship between organizational alienation and organizational citizenship behavior was examined by means of Spearman's rank correlation coefficient. "Correlation coefficient is high when it is between $0,70-1,00$; it is mean when it is between $0,70-0,30$ and it is low when it is $0,30-0,00$ [45]". The level of significance was .05.

When evaluating items in organizational alienation, the values between 1,00 and 1,80 were accepted as "Never"; the values between 1,81 and 2,60 as "Rarely"; the values between 2,61 and 3,40 as "Sometimes"; the values between 3,41 and 4,20 as "Usually"; the values between 4,21 and 5,00 as "Always". The items in organizational citizenship behavior were accepted as 1,00-1,80 "I absolutely disagree"; 1,81-2,60 “ I disagree"; 2,61-3,40 “ I am undecided"; 3,41-4,20 "I agree" and 4,21-5,00 "I totally agree".

\section{Findings}

The findings related to the dimensions of this study are included in this part respectively.

\subsection{The Perceptions of the Teachers about the Dimensions of the Organizational Alienation}

The perceptions of the teachers about the dimensions of the organizational alienation are shown in Table 1.

Table 1. The findings of the mean and standard deviation values of the perceptions of teachers' organizational alienation dimensions

\begin{tabular}{|c|c|c|c|}
\hline Dimension & $\mathrm{M}$ & $\mathrm{SD}$ & Level \\
\hline Powerlessness & 1.94 & .61 & Rarely \\
\hline Meaninglessness & 1.66 & .67 & Never \\
\hline Normlessness & 2.16 & .82 & Rarely \\
\hline Isolation & 1.87 & .75 & Rarely \\
\hline Self-estrangement & 1.86 & .77 & Rarely \\
\hline The whole scale & 1.87 & .58 & Rarely \\
\hline
\end{tabular}

Note. M: Mean, SD: Standard Deviation. 
As seen in Table 1, the perceptions of the teachers participating in the study were detected as; powerlessness $(\mathrm{M}=1,94)$, "Rarely", meaninglessness $(\mathrm{M}=1,66)$ "Never", normlessness $\quad(\mathrm{M}=2,16), \quad$ isolation $\quad(\mathrm{M}=1,87)$, self-estrangement $(\mathrm{M}=1,86)$ and the whole scale $(\mathrm{M}=1,87)$ "Rarely". The dimension with the highest level is normlessness and the item with the lowest level is meaninglessness.

\subsection{The Perceptions of Teachers' Organizational Citizenship Behavior}

The mean and standard deviation values of the perceptions of teachers' organizational citizenship dimensions are shown in Table 2.

Table 2. The mean and standard deviation values of the perceptions of teachers' organizational citizenship dimensions

\begin{tabular}{|c|c|c|c|}
\hline Dimension & $\mathrm{M}$ & $\mathrm{SD}$ & Level \\
\hline Altruism & 4.15 & .62 & I agree \\
\hline Sportsmanship & 4.21 & .76 & I totally agree \\
\hline Conscientiousness & 4.20 & .78 & I agree \\
\hline Civic virtue & 3.86 & .74 & I agree \\
\hline The whole scale & 4.11 & .52 & I agree \\
\hline
\end{tabular}

As seen in Table 2, the perceptions of the teachers regarding organizational citizenship behaviors were detected; altruism $(M=4,15)$ "I agree", gentility $(M=4,21)$ "I totally agree", conscientiousness $(M=4,20)$, civic virtue $(M=3,86)$ and the whole scale $(\mathrm{M}=4,11)$ "I agree. The highest level is sportsmanship and the lowest one is civic virtue.

\subsection{The Relationship between Teachers' Organizational Alienation and Organizational Citizenship Behaviors}

The findings about significant difference between teachers' organizational alienation behaviors and organizational citizenship behaviors are shown in Table 3 .

As seen in Table 3, the relationship between powerlessness (the dimension of organizational alienation) and "altruism (the dimension of organizational citizenship behaviors)" is $(\mathrm{r}=-.292, \mathrm{p}<.01)$ a low-level and negative oriented correlation, the relationship between powerlessness and "sportsmanship (Gentility)" is $(\mathrm{r}=-.455, \mathrm{p}<.01)$ a mid-level and negative oriented correlation, between powerlessness and "conscientiousness" is $(\mathrm{r}=-.354, \mathrm{p}<.01)$ a mid-level and negative oriented correlation, between powerlessness and "civic virtue" is $(r=-.374, p<.01)$ a mid-level and negative oriented correlation, between powerlessness and the whole scale is $(\mathrm{r}=-.482, \mathrm{p}<.01) \mathrm{a}$ mid-level and negative oriented correlation.

The relationship between meaninglessness (the dimension of organizational alienation)and "altruism" is $(\mathrm{r}=-.317, \mathrm{p}$ $<.01)$ a mid-level and negative oriented correlation, between meaninglessness and "sportsmanship" is $(\mathrm{r}=-.403, \mathrm{p}<.01)$ a mid-level and negative oriented correlation, between meaninglessness and "conscientiousness" is $(\mathrm{r}=-.319, \mathrm{p}$ $<.01)$ a mid-level and negative oriented correlation, between meaninglessness and "civic virtue" is $(\mathrm{r}=-.319, \mathrm{p}<.01) \mathrm{a}$ mid-level and negative oriented correlation, between meaningless and the whole scale is $(r=-.477, \mathrm{p}<.01) \mathrm{a}$ mid-level and negative oriented correlation.

The relationship between normlessness (the dimension of organizational alienation)and "altruism" is $(\mathrm{r}=-.204, \mathrm{p}<.01)$ a low-level and negative oriented correlation, between normlessness and "sportsmanship" is $(\mathrm{r}=-.234, \mathrm{p}<.01)$ a low-level and negative oriented correlation, between normlessness and "conscientiousness" is $(r=-.186, \mathrm{p}<.01)$ a low-level and negative oriented correlation, between normlessness and "civic virtue" is $(\mathrm{r}=-.275, \mathrm{p}<.01)$ a low-level and negative oriented correlation, between normlessness and the whole scale is $(\mathrm{r}=-.308, \mathrm{p}<.01) \mathrm{a}$ mid-level and negative oriented correlation .

The relationship between isolation (the dimension of organizational alienation) and "altruism" is $(\mathrm{r}=-.319, \mathrm{p}<.01)$ a mid-level and negative oriented correlation, between isolation and "sportsmanship" is $(\mathrm{r}=-.267, \mathrm{p}<.01) \mathrm{a}$ low-level and negative oriented correlation, between isolation and "conscientiousness" is $(\mathrm{r}=-.201, \mathrm{p}<.01)$ a low-level and negative oriented correlation, between isolation and "civic virtue" is $(\mathrm{r}=-.381, \mathrm{p}<.01)$ a mid-level and negative oriented correlation, between isolation and the whole scale is $(r=-.396, p<.01)$ a mid-level and negative oriented correlation.

Table 3. The findings about the relationship between teachers' organizational alienation behaviors and organizational citizenship behaviors

\begin{tabular}{|c|c|c|c|c|c|}
\hline Dimensions & Altruism & Sportsmanship & Conscientiousness & Civic Virtue & The whole scale \\
\hline Powerlessness & $-.292^{* *}$ & $-.455^{* *}$ & $-.354^{* *}$ & $-374^{* *}$ & $-482^{* *}$ \\
\hline Meaninglessness & $-.317^{* *}$ & $-.403^{* *}$ & $-.319^{* *}$ & $-.319^{* *}$ & $-.477^{* *}$ \\
\hline Normlessness & $-.204^{* *}$ & $-.234^{* *}$ & $-.186^{* *}$ & $-.275^{* *}$ & $-.308^{* *}$ \\
\hline Isolation & $-.319^{* *}$ & $-.267^{* *}$ & $-.201^{* *}$ & $-.381^{* *}$ & $-.396^{* *}$ \\
\hline Self-estrangement & $-.313^{* *}$ & $-.416^{* *}$ & $-.330^{* *}$ & $-.335^{* *}$ & $-.466^{* *}$ \\
\hline The whole scale & $-.342^{* *}$ & $-.436^{* *}$ & $-.325^{* *}$ & $-.422^{* *}$ & $-.510^{* *}$ \\
\hline
\end{tabular}

$\left({ }^{*} \mathrm{p}<.05, * * \mathrm{p}<.01\right)$ 
The relationship between self-estrangement (the dimension of organizational alienation) and "altruism" is( $\mathrm{r}=$ $-.313, \mathrm{p}<.01)$ a mid-level and negative oriented correlation, between self-estrangement and "sportsmanship" is ( $\mathrm{r}=-.416$, $\mathrm{p}<.01)$ a mid-level and negative oriented correlation, between self-estrangement and "conscientiousness" is ( $\mathrm{r}=$ $-.330, \mathrm{p}<.01)$ a mid-level and negative oriented correlation, between self-estrangement and "civic virtue" is $(r=-.335, p$ $<.01)$ a mid-level and negative oriented correlation, between self-estrangement and the whole scale is $(\mathrm{r}=-.466, \mathrm{p}<.01) \mathrm{a}$ mid-level and negative oriented correlation.

The relationship between organizational alienation scale and "altruism" is $(\mathrm{r}=-.342, \mathrm{p}<.01)$ a mid-level and negative oriented correlation, between organizational alienation scale and "sportsmanship" is $(\mathrm{r}=-.436, \mathrm{p}<.01)$ a mid-level and negative oriented correlation, between organizational alienation scale and "conscientiousness" is $(\mathrm{r}=-.325, \mathrm{p}<.01)$ a mid-level and negative oriented correlation, between organizational alienation scale and "civic virtue" is $(\mathrm{r}=$ $-.422, \mathrm{p}<.01$ ) a mid-level and negative oriented correlation, between organizational alienation scale and organizational citizenship scale is $(\mathrm{r}=-.510, \mathrm{p}<.01)$ a mid-level, significant and negative oriented correlation. Accordingly, it can be said that the highest level of the relationship is detected between the whole two scales.

\section{Discussion}

In this part, the results of the study are evaluated and discussed in relation to the results in other studies.

In this study, the relationship between organizational alienation and organizational citizenship behaviors of the teachers in state primary schools was analyzed. As a result of the study, the perceptions of organizational alienation of primary teachers'; "powerlessness" $(\mathrm{M}=1,94)$, "normlessness" $(\mathrm{M}=2,16), \quad$ isolation" $(\mathrm{M}=1,87)$, "self-estrangement" $(\mathrm{M}=1,86)$ and the whole scale $(\mathrm{M}=1,87)$ "Rarely"; "meaningless $(\mathrm{M}=1,66)$ "Never". The dimension with the highest level is "normlessness" ( $\mathrm{M}=2,16$; Rarely). According to the studies carried out by Eryılmaz [42] and Çağlayan [46], the dimension of "normlessness" is higher than other dimensions; the dimension of "meaninglessness" is the lowest. The results of these two studies support the results of current our study. According to the studies by Elma [16], Eryılmaz [42] and Çağlayan [46], teachers are alienated at the level of "Rarely". Work alienation represents the extent to which a person is disengaged from the world of work [5]. Based on this definition, it can be said that teachers' connection with their work was disrupted at the level of "Rarely". Although the results are at the level of "Rarely", it is obvious that the behaviors that are not accepted socially have turned out to be valid in order to reach the achievement goals determined by social norms. So, an individual with the feeling of normlessness loses its ties with the regulating rules of the society [15]. The dimension of "Meaninglessness" is the lowest, which can be regarded as a positive development because meaninglessness is a disharmony formed by the thought that an individual cannot evaluate himself or herself actually and that her/his behaviors are directed by someone else's will.

Alienation refers to a sense of separation of the individual from his or her own needs and from other people, both in work and non-work areas [6]. Alienation is a concept with sociological, psychological and educational roots [47] Individuals have some problems in work and family lives, which causes increased worry, apathy for self-realization, decreased rationality and decreased motivational changes, personal and social alienation. Thus, different kinds of behaviors can be observed such as the individual's apathy for the real world and less judgment ability, unwillingness to express himself/ herself, self-realization in low levels and apathy for the surroundings. Therefore, school directors should help teachers realize their expectations, should encourage democratic school atmosphere, should try to establish a strong communication, should work in coordination with administrators to make the job of teaching attractive and should endeavor to increase teachers' motivations. Moreover, school administration should enable teachers to participate in deciding and applying these decisions. The undemocratic governing/working environments of schools have created the existence of alienated teachers whose rumblings are fueling teacher empowerment: Implied throughout empowerment is teacher participation in school district decision making, a vital step for overcoming work alienation [48]. The finding that centralization and teacher alienation measures were significantly but negatively related to the quality of teaching and learning in these schools suggests that highly centralized schools may alienate teachers from their work, reduce subsequent teacher morale and motivation, and negatively influence school effectiveness and productivity as well [49].

The perceptions of the teachers participating in this study; "altruism" $(M=4.15)$, conscientiousness $(M=4,20)$, civic virtue $(M=3,86)$ and the whole scale $(M=4,11)$ "I agree". Just in the dimension of "sportsmanship" $(\mathrm{M}=4,21)$ "I totally agree". As seen in the results, the dimension with the highest level is "sportsmanship" $(\mathrm{M}=4,21)$ "I totally agree". Organ (1998) explains behaviors in this dimension as posture of tolerating the inevitable inconveniences and impositions of the work without whining and grievances [34].

The dimension with the lowest level is "civic virtue" ( $M=3,86$; I agree). Organ (1988) describes these behaviors as responsible, constructive involvement in the political process of the organization, including not just expressing opinions but reading one's mail, attending meetings, and keeping abreast of larger issues involving the organization [34]. The more employees have negative feelings, emotional burnout and doubts, the less organizational citizenship behaviors they perform. If employees have positive perceptions about their organizations, organizational support, equality, job satisfaction, organizational commitment, organizational trust, 
organizational justice, organizational identity, organizational identification, salary satisfaction, work, interest in the organization, the feeling of social responsibility and motivation, they will tend to perform organizational citizenship behaviors. Furthermore, organizational citizenship behaviors are affected by status at work, role identity, culture (values, norms and individualism-communitarians), the perception of ethical conduct, ethical climate, activity perception, administrator impression of work autonomy, leadership, leader- member exchange, the factors of the transformational leadership. The more sharing between leaders and members and the more qualities of transformational leadership, the more tendency of organizational citizenship behaviors [32]. Podsakoff and MacKenzie [35] suggest that one of the pioneering studies on organizational citizenship behavior and team effectiveness was carried out by Karambayya (1990), who concluded that high performance teams are made up of employees that exhibit high organizational citizenship behavior. Organizational citizenship behavior contributes to team effectiveness through its impact on the context in which the task is performed [25].

According to the result of the study, a negatively significant relationship was found between teachers' organizational alienation behaviors and all the dimensions of the organizational citizenship behaviors. The relationship between "powerlessness (the dimension of organizational alienation)" and "altruism (the dimension of organizational citizenship behaviors)" was detected as a low-level and negative oriented correlation. The relationship between powerlessness and other dimensions of organizational citizenship behaviors was detected as a mid-level and negative oriented correlation. Tutar [15] points out the fact that an individual whose life is directed by others feels weak and even powerless in case of powerlessness. This individual behaves with the feeling of inability to handle with his/her supervisors and rules, which causes the negative effect on organizational citizenship behaviors.

The relationship between "meaninglessness (the dimension of organizational alienation)" and the whole dimensions of organizational citizenship behavior was detected as a mid-level and negative-oriented correlation. It can be observed that an individual with meaningless has the inability to evaluate himself/herself actually and that there seems to be a disharmony caused by the thought that his/her behaviors are directed by other people's will and the perception of powerlessness with the feeling of inability to control the results of his/her actions [15]. Accordingly, it is not expected for employees to perform organizational citizenship behaviors.

A mid-level and negative oriented correlation between the dimension of normlessness and all the dimensions of organizational citizenship behaviors was detected. As mentioned before, an individual with normlessness loses his ties with the society's regulating rules and behaves in a way that is not accepted socially [15]. Socially unaccepted behaviors are adopted in order to achieve goals [50]. Thus, employees cannot perform reliable organizational citizenship behaviors.

The relationship of isolation (the dimension of organizational alienation) with "sportsmanship and conscientiousness (the dimensions of the organizational citizenship)" was ascertained to be a low-level and negative oriented correlation. The relationship of isolation (the dimension of organizational alienation) with "altruism and civic virtue (the dimensions of organizational citizenship behaviors)" was detected as a mid-level and negative oriented correlation. Individuals cannot make friends, interact with people and they live socially away from the community. Employees cannot participate in groups and build a relationship in harmony within the organization [15]. It is not expected from this kind of employees to perform organizational citizenship behaviors.

A mid-level and negative oriented correlation was found between the dimension of self-strangement and all the dimensions of organizational citizenship behaviors. Individuals are estranged from their selves. An alienated person is not satisfied with the factors that are normally satisfying or $\mathrm{s} / \mathrm{he}$ is not interested in those factors [15]. An individual with this feeling cannot perform organizational citizenship behaviors.

In the study, a mid-level, significant and negative oriented correlation was found between organizational alienation and organizational citizenship behaviors $(\mathrm{r}=-.510, \mathrm{p}<.01)$. The less organizational alienation, the more organizational citizenship behaviors. Mendoza-Suárezand Lara [51] suggests that the strategy to prevent work alienation strengthens healthy relationship and behaviors among employees. They point out the fact that work alienation affects behaviors in the organization negatively and administrators should establish working conditions that are compatible with humanitarian needs.

The effects of work alienation on employees are the loss of job and life satisfaction, low-productivity, low motivation, increasing work stress, low loyalty to work and organization, high labor turnover, absenteeism, estrangement from work and low perception of organizational well-being. The productivity of the employees spending most of their lives in organizations depends on personal and organizational well-being conditions. The inability of the employees to control work processes and products, the form of organizations based on automation, close supervision and authority issues, the inability of individuals to realize themselves cause organizational well-being problems [15]. Self-estrangement occurs when an employee does not find their job satisfactory [52]. All forms of teacher dissatisfaction engender feelings of alienation and that the oppressive nature of alienation is the root cause of all the negative consequences associated with teacher dissatisfaction [53].

Organizational citizenship behaviors are crucial to organizations because employees cannot perform behaviors 
for the success of organizations just with the defined rules. George and Brief (1992) suggest that organizational citizenship behavior is essential because organizations cannot anticipate through formally stated in-role descriptions the entire array of behaviors that are needed achieving goals [54]. In educational organizations, the success of students and school increases due to organizational citizenship behaviors such as teachers' working to help students learn the subjects that they do not understand in their breaks or after-school time, teaching difficult subjects with great care, making essential preparations for the lessons, performing student-centered teaching, guiding new teachers, sharing materials with colleagues, helping teachers with heavy work load and participating in extracurricular activities. Furthermore, there are more examples of organizational citizenship behaviors at schools; teachers take the classes when their colleagues do not come, they are open to self-development, they do not waste time on useless subjects, they represent their schools, they come to work on time regardless of any bad conditions, they are interested in developments related to their job, they are eager to implement innovations [55].

\section{Recommendations for Practitioners and Researchers}

Some recommendations for practitioners and researchers are as follow: (1) According to the research results, it is essential to establish a proper environment for educational and training activities and to take into account teachers' demands in the occupational and organizational fields. Within this context, teachers' expectations related to their occupations should be determined and criteria preventing teachers' alienation concerning these expectations should be developed. (2) The empowerment of communication within the organization, democratic leader, transparent management style, open communication channels, and teachers' value judgments should be borne in mind in order to prevent alienation.(3) School administrators should establish a working environment in which less alienation is experienced and more citizenship behaviors are encouraged by providing teachers with humanitarian working conditions. (4) School administrators should involve teachers, educational employees, in making and applying decisions related to them by acting responsibly. Furthermore, school administrators should avoid the applications that weaken or disregard teachers' value judgments and should establish open school climate. (5) Powerlessness (the dimension of organizational alienation) was detected to be the highest in the research. Thus, school administrators should endeavor to enable teachers to collaborate by inhibiting every application that will damage their perceptions of justice and equality by preventing teachers' alienation and estrangement. (6) A mid-level, significant and negative oriented correlation was detected between teachers' organizational alienation and citizenship behaviors and it was found out that the more organizational alienation behaviors, the less organizational citizenship behaviors. In that case, the effect of organizational alienation on teachers show itself as loss of job and life satisfaction, low productivity, low motivation, high work stress, low royalty to work and organization, high level of turnover, absenteeism, estrangement from work and low perception of organizational well-being. As a result, the harm of organizational alienation and the benefits of organizational citizenship behaviors should be explained to teachers via seminars and in-service training by experts. (7) Research can be performed by means of observations and interviews. (8) The effect of organizational alienation and citizenship behaviors of teachers on students' success can be researched. (9) Similar studies can be made comparing public and private schools.

Note: This study was formed and partially developed from Emel AVERBEK's master thesis prepared in the consultation of Asst. Prof. Dr. Abidin DAĞLI.

\section{REFERENCES}

[1] Yalçın, İ. \& Koyuncu, S.C. (2014). Örgütsel yabancılaşma olgusunun iş tatmini üzerine etkisi: Niğde İlinde bir araştırma [The effect of the phenomenon of organizational alienation on work satisfaction: A research in Nigde]. KMÜ Sosyal ve Ekonomik Araştırmalar Dergisi [KMU Journal of Social and Economic Research], 16 (26), 86-94.

[2] Akyıldız, H. (1998). Bireysel ve toplumsal boyutlariyla yabancilaşma [Alienation with its personal and social dimension]. Süleyman Demirel Üniversitesi İ.I.B.F. Dergisi [Suleyman Demirel University Journal of Faculty of Economics and Administrative Sciences], 3(3), 163-176. (In Turkish). Available at http://www.egitimbirsen.org.tr/ebs_files/files/yayinlarimiz/14 9-egitimbirsen.org.tr-149.pdf. Accessed 11 May 2013.

[3] Kongar, E. (1979). Toplumsal Değişim Kuramlarl ve Türkiye Gerçeği [Theories of Social Change and the Truth of Turkey]. Ankara: BilgiYayınevi.

[4] Horowitz, I.L. (1966). On alienation and the social order. International Phenomenological Society, 27 (2), 230-237.

[5] Hirschfeld, R.R. \& Field, H. S. (2000). Work centrality and work alienation: Distinct aspects of a general commitment to work. Journal of Organizational Behavior, 21 (1), 789-800.

[6] Lang, D. (1985). Preconditions of three types of alienation in young managers and professionals. Journal of Occupational Behavior, 6 (3), 171-180

[7] Yadav, G. K. \& Nagle, Y.K. (2012). Work alienation and occupational stress. Social Science International, 28 (2), 333-334.

[8] Sookoo, N. (2014). Perceptions of injustice and alienation dynamics within the workplace. Journal of the Department of Behavioral Sciences, 3(1), 81-99. 
[9] Raselekoane, N.R. (2008). Social theory of alienation and psychoanalysis: Towards an understanding of human alienation and insanity in E.S. Madima's A siene. South African Journal of African Languages, 28(1), 59-68.

[10] Erjem, Y. (2005). Eğitimde yabancılaşma olgusu ve öğretmen: Lise öğretmenleri üzerinde sosyolojik bir araştırma [The phenomenon of alienation in education: A sociological research on high school teachers] Gazi ÜniversitesiTürk Eğitim Bilimleri Dergisi [Gazi University Journal of Turkish Educational Sciences], 4 (3), 1-22.

[11] Agarwal, S. (1993). Influence of formalization on role stress, organizational commitment, and work alienation of salespersons: A cross- national comparative study. Journal of International Business Studies, 24(4), 715-739. Available at $\mathrm{http} / / /$ search.proquest.com/docview/197154431?pq-origsite $=\mathrm{s}$ ummon. Accessed 01 May 2016.

[12] Ceylan, A. \&Sulu, S. (2011). Organizational injustice and work alienation. Ekonomika a Management, 14(2), 65-78. Available at $\mathrm{http} / / /$ dicle.summon.serialssolutions.com/search?s.q. Accessed 17 January 2014.

[13] Seeman, M. (1959). On the meaning of alienation. American Sociological Review, 24(6), 783-791. Available at http://www.jstor.org/stable/2088565?pq-origsite=summon. Accessed 28 October 2014.

[14] Eryılmaz, A. \& Burgaz, B. (2011). Lise öğretmenlerinin örgütsel yabanc1laşma düzeyleri [Levels of organizational alienation for private and state high school teachers]. Eğitim ve Bilim [Education and Science], 36(161), 271-286.

[15] Tutar, H. (2014). Örgütsel Psikoloji [Organizational Psychology]. Ankara: DetayYayıncılık

[16] Elma, C. (2003). Work Alienation of Primary School Teachers. Unpublished doctoral thesis. Ankara: Ankara University.

[17] Efraty, D., Sirgy, J. M. \&Claiborne, C.B. (1991). The effects of personal alienation. Journal of Business and Psychology. 5(1), 52-78 Available at http://tz9hk7xh4g.search.serialssolutions.com/?ctx_ver. Accessed 23 March 2015.

[18] Nettler, G. (1957). A measure of alienation. American Sociological Review, 22(6), 670-677. Available at http://tz9hk7xh4g.search.serialssolutions.com. Accessed 05 October 2015

[19] Sidorkin, A.M. (2004). In the event of learning alienation and participative thinking in education. Educational Theory, 54 (3), 251-262.

[20] Hoşgörür, V. (1997).Eğitim Işgörenlerinin Örgütsel Tutumlart Samsun Ili [Organizational Behaviors of the Teachers: Samsun Sample]. Unpublished doctoral thesis. Ankara: Ankara University.

[21] Gürbüz, S. (2006). Örgütsel vatandaşlık davranışı ile duygusal bağl1lı arasındaki ilişkilerin belirlenmesine yönelik biraraştırma [A research on identifying the relationships between organizational citizenship Behavior and affective commitment].Ekonomik ve Sosyal Araştırmalar Dergisi [Journal of Economics and Social Studies], 3(1,3),48-75. Available at

http://abant-izzet-baysal-universitesi.dergipark.gov.tr/esad/iss ue/6045/81339. Accessed 14 March 2015.
[22] Bolino, M.C. (1999). Citizenship and impression management: Good soldiers or good actors? Academy of Management Review, 24, 82-98. Available at

$\mathrm{http}: / /$ search.proquest.com/docview/210946646?pq-origsite $=\mathrm{s}$ ummon. Accessed 15 June 2013.

[23] Gyekye, S.A. \& Haybatollahi, M. (2015). Organizational citizenship behavior: An empirical investigation of the impact of age and job satisfaction on Ghanaian industrial workers. International Journal of Organizational Analysis, 23(2), 285-301. Available at http://search proquest.com / docview / 1679403958 ?pq-origsite=summon. Accessed 15 May 2016.

[24] George, J.M. (1992). The role of personality in organizational life: Issues and evidence. Journal of Management, 18:185-213. Available at http://search.proquest.com/docview/215258078?pq-origsite $=$ S ummon. Accessed 12 March 2015.

[25] Mahembe, B. \& Engelbrecht, A.S. (2014). The relationship between servant leadership, organizational citizenship behavior and team effectiveness. SA Journal of Industrial Psychology/SA TydskrifvirBedryfsielkunde, 40(1): Art. \#1107, 10 pages. http://dx.doi.org/10.4102/ sajip.v40i1.1107.

[26] Bateman, T.S. \& Organ, D. W. (1983). Job satisfaction and the good soldier: The relationship between affect and employee citizenship. Academy of Management Journal, 26(4), 587-595 Available at http://dicle.summon.serialssolutions.com/search? s.q $=$ Job + satisfaction + and + the + good + soldie\#. Accessed 10 October 2014

[27] Tansky, J.W. (1993). Justice and organizational citizenship behavior: What is the relationship? Employees Responsibilities and Rights Journal, 6:195-207. Available at http://tz9hk7xh4g.search.serialssolutions.com/?ctx_ve. Accessed 07 December 2014

[28] Deluga, R.J. (1994). Supervisor Trust building, leader-member exchange and organizational citizenship behavior. Journal of Occupational and Organizational Psychology, 67:315-326. Available at http://tz9hk7xh4g.search.serialssolutions.com/?ctx_ver. Accessed 14 March 2015.

[29] Moorman, R.H. (1991). Relationship between organizational justice and organizational citizenship behavior: do fairness perceptions influence employee citizenship? Journal of Applied Psychology, 76, 845-855. Available at http://tz9hk7xh4g.search.serialssolutions.com. Accessed 15 June 2013.

[30] Moorman, R.H. (1993). The influence of cognitive and affective based job satisfaction measures on the relationship between satisfaction and organizational citizenship behavior. Human Relations, 46, 759-775. Available at http://search.proquest.com/docview/1290448359?pq-origsite =summon. Accessed 20 May 2014 .

[31] Niehoff, B.P. \&Moorman, R.H. (1993). Justice as a mediator of the relationship between methods of monitoring and organizational citizenship behavior. Academy of Management Journal, 36(3), 527-556. Available at http://search.proquest.com/docview/1305650729?pq. Accessed 10 October 2015.

[32] Polat, S. (2007). Ortä̈ğretim Öğretmenlerinin Örgütsel Adalet Algıları, Örgütsel Güven Düzeyleri Ile Örgütsel Vatandaşlık Davranışları Arasındaki Ilişki [Relation Between Organizational Justice Perceptions, Organizational Trust 
Levels and Organzational Citizenship Behaviors of Secondary Education Teachers]. Unpublished doctoral thesis. Kocaeli: Kocaeli University.

[33] Wang, L., Howell, J.P., Hinrichs, K.T. \& Prieto, L. (2013). Organizational citizenship behavior. Journal of Leadership and Organizational Studies, 18(1):14-24. Available at http://jlo.sagepub.com/content/18/1/14 $\square$. Accessed 19 December 2011.

[34] Podsakoff, P.M., MacKenzie, S.B., Paine, J.B. \&Bachrach, D.G. (2000). Organizational citizenship behaviors: A critical review of the theorical and empirical literature and suggestions for future research. Journal of Management, 26(3), 513-563. Available at http://jom.sagepub.com/content/26/3/513. Accessed 12 February 2014

[35] Podsakoff, P.M. \& McKenzie, S.B. (1997). Impact of organizational citizenship behavior on organizational performance: A review and suggestions for future research. Human Performance, 10(2), 133-151. Available at http://www.tandfonline.com/doi/abs/10.1207/s15327043hup1 002 5. Accessed 20 May 2014.

[36] Chiang, C.F. \& Hsieh, T. S. (2012). The impacts of perceived organizational support and Psychological empowerment on job performance. International Journal of Hospitality Management, 31(1), 180-190. Available at http://www.sciencedirect.com/science/article/pii/S027843191 1000685. Accessed 22 April 2015

[37] Somech, A. \& Ron, I. (2007). Promoting organizational behavior in schools. Educational Administration Quarterly, 43(1):38-66. Available at

http://eaq.sagepub.com/content/43/1/38. Accessed 14 April 2013

[38] DiPaola, M.F. \& Hoy, W.K., (2005). Organizational citizenship of faculty and achievement of high school students. The High School Journal, 88(3), 25-44. Available at http: // search.proquest.com/docview/220219607?pq-origsite $=$ summ on. Accessed 14 April 2015.

[39] Bogler, R. \& Somech, A. (2004). Influence of teacher empowerment on teachers' organizational commitment, professional commitment and organizational citizenship behavior in schools. Educational Administration Quarterly, 43(1), 277-289. Available at http://www.sciencedirect. com/science/article/pii/S0742051X04000125. Accessed 23 May 2014.

[40] Schoeman, S. (2006). A blueprint for democratic citizenship education in South African public schools: African teachers' perceptions of good citizenship. South African Journal of Education, 26(1), 129-142.

[41] Karasar, N. (2009). Bilimsel Araştırma Yöntemi [Methods of Scientific Research]. Ankara: Nobel Yayınları.

[42] Ery1lmaz, A. (2010). Lise Öğretmenlerinin Örgütsel Yabancılaşma Düzeyleri [Levels of Organizational Alienation for High School Teachers]. Unpublished master thesis. Ankara: Hacettepe University.

[43] Sipahi, B., Yurtkoru, S. \& Çinko, M. (2010). Sosyal Bilimlerde SPSS'le veri Analizi. [Data Analysis with SPSS in Social Studies]. İstanbul: Beta BasımYayım Dağıtım.
[44] Tavşancıl, E. \& Keser, H. (2001). İnternete Yönelik Likert Tipi Bir Tutum Ölçeğinin Geliştirilmesi. [The Development of A Likert Type-Attitude Scale Towards Internet Usage]. Ankara University Journal of Educational Sciences, 34 (2), 45-60.

[45] Büyüköztürk, Ş. (2014). Sosyal Bilimler İcin Veri Analizi El Kitabr [Data Analysis for Social Studies] Ankara: Pegem A Yayıncilik.

[46] Çağlayan, A. (2015). Perceptions of Imam Hatip Secondary School Teachers Regarding Work Alienation. Unpublished master thesis. Gaziantep: Zirve University.

[47] Hascher, T \& Hagenauer, G. (2010). Alienation from school. International Journal of Educational Research, 49, 220-232. Doi:10.1016/J.İjer.2011.03.002.

[48] Vavrus, M. (1989). Alienation as the conceptual foundation for incorporating teacher empowerment into the teacher education knowledge base proceedings of the national forum of the independent liberal arts colleges for teacher education, 2-4 June, Indianapolis. Available at http://files.eric.ed.gov/fulltext/ED344851.pdf. Accessed 0904 2017

[49] Johnson, B.L. \&Ellet, C.D. (1992). Analyses of school level learning environments centralized decision making teacher work alination and organizational effectiveness, Educational Management, 20 (4), 1-42.

[50] Tolan, B. (1981). Că̆daș Toplumun Bunalımı Anomi ve Yabanculaşma [Anomie: The Crisis of Contemporary Society and Alienation]. Ankara: Academic publications of Ankara Economic and Trade Sciences.

[51] Mendoza-Suárez, M.J. \& Lara, P.Z.M. (2007). The impact of work alienation on organizational citizenship behavior in the Canary Islands. International Journal of Organizational Analysis, 15(1):56-76. Available at http://search.proquest.com/docview/198613593?pq-origsite $=\mathrm{s}$ ummon. Accessed 12 April 2014.

[52] Tan-Uçanok, B. (2016). The role of work centrality in the relationship between work alienation and organisational commitment. Journal for East European Management Studies. $21(1), 60-81$

[53] Soza, J. (2015). Teacher Alienation: Reconceptualizing The Educational Work Environment the Faculty of the School of Education, A doctoral dissertation Loyola Marymount University, USA.

[54] Vanyperen, N.W., den Berg, A.E. \& Willering, M.C. (1999). Towards a better understanding of the link between participation in decision-making and organizational citizenship behavior: A multilevel analysis. Journal of Occupational and Organizational Psychology, 72:377-392. Available at http://search.proquest.com/docview/1634124296?pq-origsite =summon. Accessed 24032016

[55] Demiröz, S. (2014). The relationship between the teachers' organizational citizenship behavior, organizational image perceptions and the student's success. Unpublished master thesis. Ankara: Hacettepe University. 